\title{
Usability of the Upper Limb Risk Assessment (UPLIRA) Method for Assessing the Risk Factors of Upper Limb Disorders
}

\author{
Noor Syafiqa Abd Razak and Mohd Nasrull Abdol Rahman* \\ Department of Manufacturing and Industrial Engineering, Faculty of Mechanical and Manufacturing \\ Engineering, Universiti Tun Hussein Onn Malaysia (UTHM), 86400 Batu Pahat, Johor, Malaysia.
}

\begin{abstract}
It is important to design ergonomic methods or assessment with a high usability and good ergonomic features, so the method is easily adaptable to the task and the workplace environment. Usability is a measurement on how well the user can use that functionality. The study converged on testing the usability of the new tools for assessing ULDs namely as Upper Limb Risk Assessment (UPLIRA). The UPLIRA method was evaluated by 6 students ( 3 undergraduate students and 3 postgraduates students) from University Tun Hussein Onn Malaysia (UTHM) who are conducting research in ergonomic. From the feedback survey of UPLIRA method, the observers agree that the prototype of UPLIRA tool was applicable to workplace assessment for the wide range of jobs/task (mean 4.00, SD:0.632) with $83 \%$ percentage of agreement . They also indicate that UPLIRA method is quick to use (mean 3.67, SD:1.033) with percentage agreement of $67 \%$. The scoring system and action level was rated as easy to understand (mean 3.67, SD:1.211) and (mean 4.17, SD:0.408). Conclusively, the UPLIRA method was rated as straightforward to use, applicable to wide range of tasks, and time saving as assessment can be completed within 10 minutes. In addition, the UPLIRA assessment covers an extensive range of physical, psychosocial, work organizational, and individual risk factors.
\end{abstract}

\section{Introduction}

Upper limb disorders (ULDs) are injury that affected the upper part of the body including neck, shoulders, elbows, wrists, and upper back [1]. ULDs correspondingly cause disability, absenteeism, pain, heavy financial costs among workers worldwide, and reduced productivity [2-3]. Prolonged exposure to risk factors at workplace may contribute to the occurrence of occupational health disorders and development of occupational diseases such as repetitive movements, awkward posture, forceful exertion, awkward posture, and vibration [3-4]. In addition, the previous study reported that psychological and individual factors such as gender, age, BMI, smoking, and anthropometry also play a role in the development of ULDs [5]. The psychosocial factors such as workload, job dissatisfaction, limited social support, time pressure and limited job control further increase the potential for the worker to get an upper limb disorders [5]. However, only a few studies have considered the multifactor association of job, individual, and psychosocial factors in assessing the prevalence of ULDs [6].

*Corresponding author : mnasrull@uthm.edu.my 
Pen and paper based observational methods are probably the most frequently used to evaluate physical workloads in order to identify hazards at workplace. The number of available methods are large, but no single method is suitable for all purposes. Since, different methods often focus on different exposures, it may be worth to combine several methods to perform a more comprehensive risk assessment [7]. The current techniques for assessing exposure to risk factors associated with ULDs includes Rapid Upper Limb Assessment (RULA) [8], Job Strain Index (JSI) [9], Occupational Repetitive Actions (OCRA) [10], Cumulative Trauma Disorders (CTD) [11], Loading on the Upper Body Assessment (LUBA) [12], Upper Limb Disorders (ULDs) Health and Safety Guide (HSG60) [13], and Assessment of Repetitive Task (ART) [14]. From the objective for each tool, it can be concluded that the aim was to not entirely fixate on assessing the work-related upper limb disorders. Most of them only focused on general ergonomic risks [15].

It is substantial to design ergonomic methods or assessment with a high usability and good ergonomic features, so the method is adaptable to the task and the workplace environment. Usability measured the ability of a user to use that functionality [16]. In the study of [17-18] found that the usability of ART has the highest mean score. Meanwhile, the lowest rated method was the OCRA checklist. The OCRA checklist also required a relatively extensive period in average for assessment. This is probably because the ART tool is simpler as compared to OCRA checklist. Therefore, the main objective of this study is to test the usability of the new tools for assessing ULDs namely as Upper Limb Risk Assessment (UPLIRA).

\section{Method}

\subsection{Study Design Data Collected}

The prototype was evaluated by 6 students ( 3 under graduate students and 3 postgraduates students) from University Tun Hussein Onn Malaysia (UTHM) who are conducting research in ergonomic. Firstly, the participants were given a brief discussion about the purpose of the tool, the applications of UPLIRA, the instructions, the scoring system, action level system, and exposure level. Then, all the participants were briefed on how to conduct an UPLIRA assessment for about 1 hour during the day. The video of 3 different tasks being performed such an operator in packaging section, a cashier, and an accountant was presented. After that, the participants made their assessment on each recorded task. The video was re-played to ensure that all observers could complete their assessment on that particular task. About 10 minutes were taken by the observers to evaluate each task.

After the observers completed all their assessment, they fill out the feedback survey questions to evaluate the usability of the UPLIRA method. The questionnaire comprises 3 parts; part 1 consists of 13 questions about the UPLIRA method such as, simple and quick operation, the clarity and conciseness of the instructions, the readability of the wordings, the clarity and conciseness of the pictures/illustrations, level of results interpretation of scoring system, understandability of the score for each items, understandability of the final score and action level applicability towards workplace assessment, applicability in wide range of jobs/tasks, valuable at works (cost effective) and valuable at works (provide a good basis for intervention proposals) as shown in Figure 1. These closed-ended questions were rate with five point Likert scale $(1=$ strongly disagree, $5=$ strongly agree). Part 2 on the other hand consist of overall comments and suggestions for UPLIRA method and Part 3 consist of comments and suggestions for each part as shown in Figure 1 and 2. 


\section{Feedback Survey for Usability of Upper Limb Risk Assessment (UPLIRA) Method}

The UPLIRA method is designed to assess the risk factors of Work-related Upper Limb Disorders (WRULDs) at work place that including the upper body regions such as neck, shoulders, elbows, wrists, and back that contribute to the development of Work-related Upper Limb Disorders (WRULDs). Risk factors cover for this tool are physical, psychosocial, work organizational and individual risk factors. This objective of this survey are developed to identify the usability of the UPLIRA method for user and practitioners.

Name:

Age (Years):

Job Position:

Working Experienced (Years):

Education Level: Date:

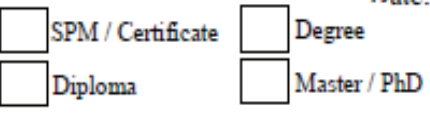

Please circle the answer that best represents your rating for each statement and add comments in order to help us understand better your opinion.

\begin{tabular}{|c|c|c|c|c|}
\hline $\mathbf{l}$ & $\mathbf{2}$ & $\mathbf{3}$ & $\mathbf{4}$ & $\mathbf{5}$ \\
\hline Strongly Disagree & Disagree & Not Sure & Agree & Strongly Agree \\
\hline
\end{tabular}

\begin{tabular}{|c|c|c|c|c|c|c|}
\hline No. & Question & \multicolumn{5}{|c|}{ Rating } \\
\hline 1 & Easy to use and straightforward & 1 & 2 & 3 & 4 & 5 \\
\hline 2 & Quick to use & $\mathrm{l}$ & 2 & 3 & 4 & 5 \\
\hline 3 & Instructions is clearly to read and understand & 1 & 2 & 3 & 4 & 5 \\
\hline 4 & Wordings is clearly to read and understand & l & 2 & 3 & 4 & 5 \\
\hline 5 & Pictures/illustrations is clearly to see and understand & 1 & 2 & 3 & 4 & 5 \\
\hline 6 & Scoring system is easy to interpret the results & l & 2 & 3 & 4 & 5 \\
\hline 7 & Score for each items is easy to understand & 1 & 2 & 3 & 4 & 5 \\
\hline 8 & Final score is easy to understand & $\mathrm{l}$ & 2 & 3 & 4 & 5 \\
\hline 9 & Action level is easy to understand & $\mathrm{l}$ & 2 & 3 & 4 & 5 \\
\hline 10 & Applicable to workplace assessment & 1 & 2 & 3 & 4 & 5 \\
\hline 11 & Applicable to wide range of jobs/tasks & 1 & 2 & 3 & 4 & 5 \\
\hline 12 & Valuable at works (cost effective) & 1 & 2 & 3 & 4 & 5 \\
\hline 13 & $\begin{array}{l}\text { Valuable at works (provide a good basis for intervention } \\
\text { proposals }\end{array}$ & 1 & 2 & 3 & 4 & 5 \\
\hline
\end{tabular}

a) Overall comments for UPLIRA method (if any)

b) Suggestions or recommendations for UPLIRA method (if any)

Fig 1. Part 1 and Part 2 of UPLIRA usability feedback questions. 
c) Comments and suggestions for each part (if any)

\begin{tabular}{|c|c|c|}
\hline Items & Comments & Suggestions \\
\hline $\begin{array}{l}\text { Part 1: Physical Risk Factors } \\
\text { A - Awhward Posture: } \\
\text { A1 - Neck } \\
\text { A2 - Sboulders } \\
\text { A3 - Elbows } \\
\text { A4 - Wrists } \\
\text { A5 - Back } \\
\text { B - Force / Load } \\
\text { B1 - Lifting / Lowering } \\
\text { B2 - Pushing / Pulling } \\
\text { B3 - Gripping / Pinching } \\
\text { C - Vibration } \\
\text { D - Temperature } \\
\text { E - Noise Level } \\
\text { F - Lighting Level }\end{array}$ & & \\
\hline $\begin{array}{l}\text { Part 2: Psychosocial Rislk Factors } \\
\text { G1 - Lack of support from supervisors of co-workers } \\
\text { G2 - Difficult to keep up with their work } \\
\text { G3 - Frequent tight deadlines to meet } \\
\text { G4 - Task requires high levels of atrention and concentration } \\
\text { G5 - Overtimeshift work that is unplanned } \\
\text { G6 - Sufficient training and information } \\
\text { G7 - Sudden changes in workload } \\
\text { G8 - Job/role is lacking in importance to your organization } \\
\text { G9 - If your friends interested in working in your job, what } \\
\text { would you tell him/her } \\
\text { G10 - How satisfied would you say you are with your job }\end{array}$ & & \\
\hline $\begin{array}{l}\text { Part 3: Work Organizational Risk Factors } \\
\text { H1 - Job require you to work hard } \\
\text { H2 - How often can you use the skills from your previous } \\
\quad \text { experience and training } \\
\text { H3 - Relationship berween others employees is hamonious in } \\
\text { attaining the overall organizational goals } \\
\text { H4 - Does your company give wage inceutives? }\end{array}$ & & \\
\hline $\begin{array}{l}\text { Part 4: Individual Risk Factors } \\
\text { I1 - How any of each of the following do you smoke } \\
\text { (Cigarette per day) } \\
\text { I2 - During the past } 6 \text { months, have you bad any on the job } \\
\text { accidents? } \\
\text { I3 - Within the past } 12 \text { months, has the kind or amount of } \\
\text { work you can do been limited by any disabilities } \\
\text { I4 - Was this disability caused by your job? } \\
\text { I5 - Was this disability a result of an accident at work? } \\
\text { I6 - Have you applied for financial benefits as a result of this } \\
\text { disability } \\
\text { I7 - Do you currently receive financial benefits as a result of } \\
\text { this disability? }\end{array}$ & & \\
\hline
\end{tabular}

Fig. 2. Part 3 of UPLIRA usability feedback questions 


\subsection{Data Analysis}

Statistical analysis was performed using Statistical Package for Social Sciences (SPSS) version 22. The feedback survey was presented as mean, standard deviation (SD) and percentage.

\section{Results and Discussion}

This section discussed the feedback for usability of UPLIRA tool, general comment, and suggestion for UPLIRA tool, and specific comments and suggestion for UPLIRA tool. From the result, the observers $(n=6)$ indicates that the prototype of UPLIRA tool was easy to use and straightforward (mean 3.60 SD:1.140), quick to use (mean 3.67 SD:1.033), instructions is clearly to read and understand (mean 3.17 SD:0.753), wordings is clearly to read and understand (mean $3.33 \mathrm{SD}: 0.816$ ), pictures or illustrations is clearly to see and understand (mean $3.83 \mathrm{SD}: 0.753$ ), scoring system is easy to interpret the results (mean 3.67 $\mathrm{SD}: 1.211$ ), score for each items is easy to interpret the results (mean 3.50 SD:1.049), final score is easy to understand (mean 3.67 SD:1.506), action level is easy to understand (mean 4.17 SD:0.408), applicable to workplace assessment (mean 4.00 SD:0.632), applicable to wide range of jobs/tasks (mean 4.17 SD:0.753), valuable at works which is cost effective (mean 4.17 SD:0.753), and finally valuable at works which provide a good basis for intervention proposals (mean $4.17 \mathrm{SD}: 0.753$ ). Figure 1 tabulated the results of percentage feedback survey of usability from 6 observers ( 3 undergraduate students and 3 postgraduate students). Table 1 shows the observers rating of feedback surveys for usability of UPLIRA method.

Table 1. Observers ratings of feedback survey of UPLIRA method ( $n=6$ observers)

\begin{tabular}{|c|l|c|c|c|c|c|c|}
\hline \multirow{2}{*}{ No Questions } & \multicolumn{1}{|c|}{ Rating Score } & Total Score \\
\cline { 3 - 8 } & & $\mathbf{1}$ & $\mathbf{2}$ & $\mathbf{3}$ & $\mathbf{4}$ & $\mathbf{5}$ & Mean (SD) \\
\hline 1 & Easy to use and straightforward & - & 1 & 2 & 2 & 1 & $3.60(1.140)$ \\
\hline 2 & Quick to use & - & 1 & 1 & 3 & 1 & $3.67(1.033)$ \\
\hline 3 & $\begin{array}{l}\text { Instructions is clearly to read and } \\
\text { understand }\end{array}$ & - & 2 & 2 & 2 & - & $3.17(0.753)$ \\
\hline 4 & $\begin{array}{l}\text { Wordings is clearly to read and } \\
\text { understand }\end{array}$ & - & - & 3 & 3 & - & $3.33(0.816)$ \\
\hline 5 & $\begin{array}{l}\text { Pictures/illustrations is clearly to see } \\
\text { and understand }\end{array}$ & - & - & 2 & 3 & 1 & $3.83(0.753)$ \\
\hline 6 & $\begin{array}{l}\text { Scoring system is easy to interpret the } \\
\text { results }\end{array}$ & - & 1 & 2 & 1 & 2 & $3.67(1.211)$ \\
\hline 7 & $\begin{array}{l}\text { Score for each item is easy to } \\
\text { understand }\end{array}$ & - & 1 & 2 & 2 & 1 & $3.50(1.049)$ \\
\hline 8 & Final score is easy to understand & 1 & - & - & 3 & 2 & $3.67(1.506)$ \\
\hline 9 & Action level is easy to understand & - & - & 1 & 4 & 1 & $4.17(0.408)$ \\
\hline 10 & Applicable to workplace assessment & - & - & 1 & 4 & 1 & $4.00(0.632)$ \\
\hline 11 & Applicable to wide range of jobs/tasks & - & - & 1 & 3 & 2 & $4.17(0.753)$ \\
\hline 12 & Valuable at works (cost effective) & - & - & 1 & 3 & 2 & $4.17(0.753)$ \\
\hline 13 & $\begin{array}{l}\text { Valuable at works (provide a good } \\
\text { basis for intervention proposals) }\end{array}$ & - & - & 1 & 3 & 2 & $4.17(0.753)$ \\
\hline
\end{tabular}

Notes: Rating scale range from 1 = strongly disagree to 5 = strongly disagree)

Figure 1 shows the percentage for feedback survey on usability of UPLIRA method. All of the observers agreed and strongly agreed that UPLIRA method is easy to use and straightforward (60\%), quick to use $(67 \%)$, instructions is clearly to read and understand 
$(83 \%)$, wordings is clearly to read and understand (50\%), picture or illustrations is clearly to see and understand (67\%), scoring system is easy to interpret the results $(50 \%)$, score for each items is easy to understand $(50 \%)$, final score is easy to understand $(67 \%)$, action level is easy to understand (100\%), applicable to workplace assessment (83\%), applicable to wide range of jobs/tasks (83\%), valuable at works which is cost effective (83\%), and lastly valuable at works which provide a good basis for intervention proposals $(83 \%)$. From the results, it is deduced that more than $50 \%$ of observers has either agreed or strongly agreed with the questions of the survey.

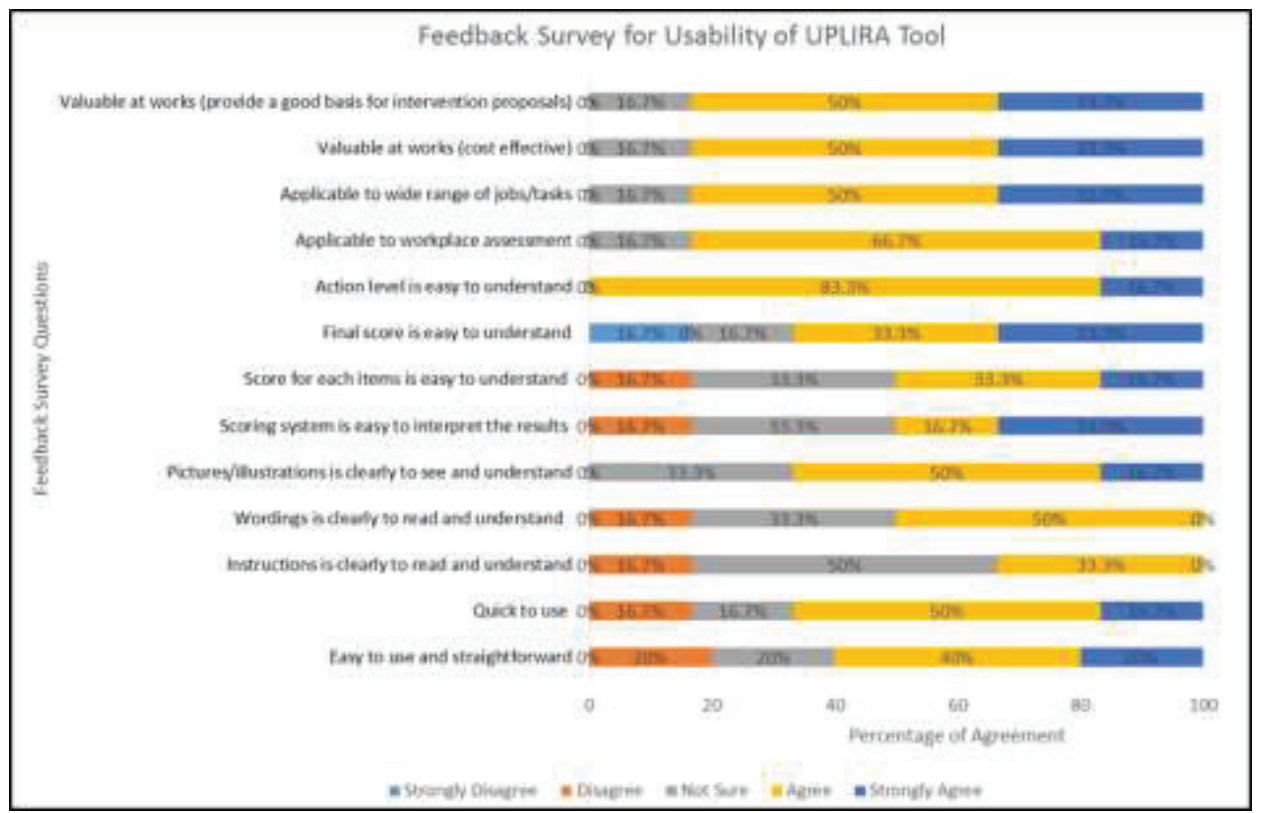

Fig. 3. The percentage agreement of feedback survey on usability of UPLIRA method

From the feedback questionnaire about usability of the UPLIRA method for all participants $(\mathrm{n}=6)$ using ratings $(1=$ strongly disagree to $5=$ strongly agree $)$, found that the action level is easy to understand with mean (mean $4.17 \pm 0.408$ ) with percentage of agree and strongly agree was $100 \%$. This is because the final score is easy to understand that lead to choosing the suitable action level. The observers considered that these prototype is applicable to wide range of job/task (mean $4.17 \pm 0.753$ ), valuable at works (mean $4.17 \pm 0.753$ ), and provide a good basis intervention proposals (mean $4.17 \pm 0.753$ ) with percentage agreement of each was $83 \%$. This is because the observers believe that the UPLIRA method can be used at different workstations. Unfortunately, the observers found that the instructions and wordings is not readable and understandable based on the relatively low score (mean $3.17 \pm 0.753$ ) and (mean $3.33 \pm 0.816$ ) with percentage of agreement of $83 \%$ and $50 \%$ respectively. This is because the observer found that the font is small and the color of figure and box of risk level is confusing. In addition, the observers found that the pictures or illustration is vague (mean $3.83 \pm 0.753$ ) and percentage agreement was $67 \%$. The observers found that the picture and the motion is confusing. In other study found that it was difficult for observers to determine the specific angle solely by observation [19]. In addition, the observers found that the UPLIRA method is not really easy to understand, time consuming with the results (mean $3.60 \pm 1.140$ ) and (mean $3.67 \pm$ 1.033 ) with percentage agreement $60 \%$ and $67 \%$ respectively. While for the scoring system and final score, the observers take more time to understand before they properly decide 
based on the score (mean $3.67 \pm 1.211$ ) and (mean $3.67 \pm 1.506$ ) with the percentage agreement was $50 \%$ and $67 \%$. The observers stated that, the UPLIRA method is applicable to workplace assessment with the score (mean $4.00 \pm 0.632$ ) with percentage agreement of $83 \%$.

Part 2 of feedback questions explored the general comments and suggestion for UPLIRA method. Most of the observers found that the left and right side is really confusing because it's not synchronized and the instructions should be explained appropriately for better understanding. Other than that, they believe that UPLIRA method can be a good reference for workplace improvement and good for ergonomic assessment especially in upper body. The UPLIRA method is confusing for the first-time user and the observers suggest that it need to be revised. Table 2 shows the summary of overall feedback comments from observers.

Table 2. The overall feedback comments from observers $(n=6)$

\begin{tabular}{|c|l|}
\hline Observers & \multicolumn{1}{c|}{ Comments } \\
\hline 1 & $\begin{array}{l}\text { The left and right side should be synchronized } \\
\text { Good references for workplace improvement. }\end{array}$ \\
\hline 2 & $\begin{array}{l}\text { Slightly confusing for the first time user } \\
\text { Good for ergonomic assessment }\end{array}$ \\
\hline 3 & $\begin{array}{l}\text { It is a good for create a new method in the ergonomic assessment tool. } \\
\text { This will be one of the alternative to reduce the risk }\end{array}$ \\
\hline 4 & $\begin{array}{l}\text { The prototype need to be revised } \\
\text { Useful tool to use } \\
\text { It is difficult to use without any reference or user guide }\end{array}$ \\
\hline 5 & $\begin{array}{l}\text { The instructions is better in circle than cross (x) } \\
\text { The left and right side should be synchronized }\end{array}$ \\
\hline 6 & $\begin{array}{l}\text { The right and left side are confusing } \\
\text { The instruction not clear } \\
\text { The words in the score box is not clear } \\
\text { The angle line is not clear }\end{array}$ \\
\hline
\end{tabular}

Table 3 shows the summary of suggestions from the observers. Some of the suggestions mentioned about using simple and short words for instruction, reducing the questions, adding more exposure level range, improving the range of angle motion, and minimizing the use of paper. The others mentioned about the technicality of the UPLIRA tool such as the keywords should be bold, increasing the size of risk level box, putting a degree $\left({ }^{\circ}\right)$ symbol in every classes of motion, and changing the color of the score box because the color of moderate box is same as the figure.

Table 3. The suggestions for UPLIRA tool $(n=6)$

\begin{tabular}{|c|l|}
\hline Observers & \multicolumn{1}{c|}{ Suggestions/recommendations } \\
\hline 1 & $\begin{array}{l}\text { Use simple words to better understanding } \\
\text { Add more exposure level }\end{array}$ \\
\hline 2 & $\begin{array}{l}\text { Make it short and simple } \\
\left.\text { Need to improve the angle range (e.g. } 0-20^{\circ}, 21-45^{\circ},>46^{\circ}\right)\end{array}$ \\
\hline 3 & $\begin{array}{l}\text { Reduce the questions } \\
\text { Add more exposure level range }\end{array}$ \\
\hline 4 & $\begin{array}{l}\text { Add more exposure level range } \\
\text { Increase the size of risk level box }\end{array}$ \\
\hline 5 & $\begin{array}{l}\text { The keywords should be bold } \\
\text { Add more exposure level range }\end{array}$ \\
\hline
\end{tabular}




\begin{tabular}{|l|l|}
\hline & Minimize the use of paper for scoring sheet \\
\hline \multirow{6}{*}{6} & $\begin{array}{l}\text { Put a degree }(\circ) \text { symbol in every classes of motion } \\
\text { Make a short and simple instruction or used symbol } \\
\text { The keywords should be bold } \\
\text { Change the color of the score box } \\
\text { Minimize the used of paper } \\
\text { Synchronized the left and right side }\end{array}$ \\
\hline
\end{tabular}

Table 4 shows shows the summary of specific comments and suggestions for UPLIRA tool. This is the third part of feedback questions from UPLIRA tool. Most of the comments and suggestions are from Part 1 of the UPLIRA prototype which is physical risk factors items and some from psychosocial and individual risk factors. The repetition for every motion should be added in the UPLIRA tool. In addition, the illustration is not clear especially for wrist motion. Unclear definitions of postures can be a source of disagreement between the assessors [20]. Most of the questions comprises of choice (OR) options and it's confusing. Furthermore, the right (R) and left (L) side should be synchronized. In addition, the noise and lighting level should be used in numerical range instead of general value such as slow, loud, very loud. While for psychosocial risk factors, the observer believes that 'always' and 'often' have the similar meaning. They suggest using another word and reduce the questions and use only ones that are related to upper limb disorders. For individual risk factors, some of the questions is confusing. The observers also imply reducing the questions and only ask the questions related to upper limb disorders.

Table 4. Specific comments and suggestions for UPLIRA tool

\begin{tabular}{|c|c|c|}
\hline Items & Comment & Suggestions \\
\hline $\begin{array}{l}\text { Part 1: Physical Risk Factors } \\
\text { A - Awkward Posture } \\
\text { A1 - Neck } \\
\text { A2 - Shoulders } \\
\text { A3 - Elbows } \\
\text { A4 - Wrists } \\
\text { A5 - Back } \\
\text { B0 - Force/Load } \\
\text { B1 - Lifting/Lowering } \\
\text { B2 - Pushing/Pulling } \\
\text { B3 - Gripping/Pinching } \\
\text { C - Vibration } \\
\text { D - Temperature } \\
\text { E - Noise Level } \\
\text { F - Lighting Level }\end{array}$ & $\begin{array}{l}\text { A1 - The color of } \\
\text { picture and column for } \\
\text { ticks are same color } \\
\text { (confuse) } \\
\text { The question is a bit } \\
\text { confuse because it has a } \\
\text { choice (OR) } \\
\text { A2 - The Right and } \\
\text { Left side a bit confused }\end{array}$ & $\begin{array}{l}\text { The instruction should be } \\
\text { a circle than the a cross } \\
\text { (x) } \\
\text { No neck extension } \\
\text { repetition column } \\
\text { Make a clear wrist } \\
\text { picture. } \\
\text { Add repetition column for } \\
\text { every motion } \\
\text { D - The position D1 and } \\
\text { D2 should be change } \\
\text { E - Should be used a } \\
\text { range instead of a value } \\
\text { (e.g. slow/loud/very loud) } \\
\text { F - Should be used a in } \\
\text { numerical range instead } \\
\text { of general value }\end{array}$ \\
\hline $\begin{array}{ll}\text { Part 2: Psychosocial Risk Factors } \\
\text { G1 } \quad \text { Lack of support from } \\
\text { supervisors and workers } \\
\text { G2 }-\begin{array}{l}\text { Difficult to keep up with } \\
\text { their work }\end{array} \\
\text { G3 }-\begin{array}{l}\text { Frequent tight deadlines } \\
\text { to meet }\end{array} \\
\text { G4 } \begin{array}{l}\text { - Task requires high levels } \\
\text { of attention }\end{array} \\
\end{array}$ & $\begin{array}{l}\text { 'Always' and 'Often' } \\
\text { have the same meaning }\end{array}$ & Reduce the questions \\
\hline
\end{tabular}


Table 4. Continue

\begin{tabular}{|c|c|c|}
\hline $\begin{array}{ll}\text { G5 } & - \text { Overtime/shift work that } \\
& \text { is unplanned } \\
\text { G6 } & - \text { Sufficient training and } \\
& \text { Information } \\
\text { G7 } & - \text { Sudden changes in workload } \\
\text { G8 }- & \text { Job/role is lacking in } \\
& \text { importance to your } \\
& \text { organization } \\
\end{array}$ & & \\
\hline $\begin{array}{l}\text { G9 - If your friends interested } \\
\text { in working in your job, what } \\
\text { would you tell him/her? } \\
\text { G10 - How satisfied would you say } \\
\text { you are with your job? }\end{array}$ & & \\
\hline $\begin{array}{l}\text { Part 3: Work Organizational } \\
\text { Risk Factors } \\
\text { H1 - Job require you to work hard } \\
\text { H2 - How often can you use the } \\
\text { skills form your previous } \\
\text { experience and training? } \\
\text { H3 - Relationship between others } \\
\text { employees is harmonious in } \\
\text { attaining the overall } \\
\text { organizational goals } \\
\text { H4 - Does your company give } \\
\text { wage incentives? }\end{array}$ & & \\
\hline $\begin{array}{l}\text { Part 4: Individual Risk Factors } \\
\text { I1 - How any of each of the } \\
\text { following do you smoke } \\
\text { (Cigarette per day) } \\
\text { I2 - During the past } 6 \text { months, have } \\
\text { you had any on the job } \\
\text { accidents? } \\
\text { I3 - Within the past } 12 \text { months, has } \\
\text { the kind or amount of work } \\
\text { you can do been limited by } \\
\text { any disabilities? } \\
\text { I4 - Was this disability caused by } \\
\text { your job? } \\
\text { I5 - Was this disability a result of } \\
\text { an accident at work? } \\
\text { I6 - Have you applied for financial } \\
\text { benefits as a result of this } \\
\text { disability? } \\
\text { I7 - Do you currently receive } \\
\text { Financial benefits as a result } \\
\text { of this disability? }\end{array}$ & $\begin{array}{l}\text { The question } \\
\text { somewhat confusing }\end{array}$ & $\begin{array}{l}\text { Reduce the questions } \\
\text { and use only related to } \\
\text { upper limb disorders }\end{array}$ \\
\hline
\end{tabular}




\section{Conclusion}

As the conclusion, the UPLIRA method was rated as it is straightforward to use, widely applicable, and time saving. In addition, the UPLIRA assessment covers an extensive range of physical, psychosocial, work organizational, and individual risk factors. Meanwhile, the disadvantages of UPLIRA assessment is that it is undoubtedly a complex method. Therefore, further refinements are required to render the UPLIRA to be a better assessment in evaluating work related ULDs

This research is funded by Office for Research, Innovation, Commercialization and Consultancy Management (ORICC) and Universiti Tun Hussein Onn Malaysia (UTHM) under 'Geran Penyelidikan Pasca Siswazah' (GPPS), Vot U594.

\section{References}

[1] A. Garg, J. M. Kapellusch. Job analysis techniques for distal upper extremity disorders. Reviews of Human Factors and Ergonomics, 7(1), 149-196 (2011).

[2] L. Punnett, D. H. Wegman. Work-related musculoskeletal disorders: the epidemiologic evidence and the debate. Journal of Electromyography and Kinesiology, 14(1), 13-23 (2004).

[3] B. M. Tinubu, C. E Mbada, A. L Oyeyemi, A. A Fabunmi. Work-related musculoskeletal disorders among nurses in Ibadan, South-west Nigeria: a crosssectional survey. BMC musculoskeletal disorders, 11(1), 12. (2010).

[4] B. R. da Costa, E. R. Vieira. Risk factors for work- related musculoskeletal disorders: a systematic review of recent longitudinal studies. American Journal of Industrial Medicine, 53(3), 285-323 (2010).

[5] B. P. Bernard. Musculoskeletal disorders and workplace factors: a critical review of epidemiologic evidence for work-related musculoskeletal disorders of the neck, upper extremity, and low back. Cincinnati, OH: U.S. Department of Health and Human Services, Centers for Disease Control and Prevention, National Institute for Occupational Safety and Health, DHHS (NIOSH) Publication No. 97-141. (1997)

[6] P. R. Mosaly. Multifactor association of job, individual and psychosocial factors in prevalence of distal upper extremity disorders and quantification of job physical exposure. International Journal of Industrial Ergonomics, 55, 40-45, (2016).

[7] E. P. Takala, I. Pehkonen, M. Forsman, G. A. Hansson, S. E. Mathiassen, W. P. Neumann, J. Winkel Systematic evaluation of observational methods assessing biomechanical exposures at work. Scandinavian journal of work, environment \& health, 3-24, (2010).

[8] L. McAtamney, E. N. Corlett. RULA: a survey method for the investigation of workrelated upper limb disorders. Applied Ergonomics, 24(2), 91-99, (1993).

[9] J. S. Moore, A. Garg, The strain index: a proposed method to analyze jobs for risk of distal upper extremity disorders. American Industrial Hygiene Association, 56(5), 443-458, (1995).

[10] E. Occhipinti. OCRA: a concise index for the assessment of exposure to repetitive movements of the upper limbs. Ergonomics, 41(9), 1290-1311, (1998).

[11] V. Seth, R. L. Weston, A. Freivalds, Development of a cumulative trauma disorder risk assessment model for the upper extremities. International Journal of Industrial Ergonomics, 23(4), 281-291, (1999).

[12] D. Kee, W. Karwowski. LUBA: an assessment technique for postural loading on the upper body based on joint motion discomfort and maximum holding time. Applied Ergonomics, 32(4), 357-366, (2001). 
[13] R. J. Graves, K. r. Way, D. Riley, C. Lawton, L. Morris. Development of risk filter and risk assessment worksheets for HSE guidance-'Upper Limb Disorders in the Workplace'2002. Applied Ergonomics, 35(5), 475-484. (2004).

[14] J. Ferreira, M. Gray, L. Hunter, M. Birtles, D. Riley. Development of an assessment tool for repetitive tasks of the upper limbs (ART). Derbyshire: Health and Safety Executive. (2009).

[15] M. N. A. Rahman, N. S. A. Razak. Review on Pen and Paper Based Observational Methods for Assessing Work-related Upper Limb Disorders. Indian Journal of Science and Technology, 9(S1), (2016).

[16] J. Nielsen. Usability engineering, Elsevier, (1994).

[17] K. Eliasson, T. Nyman, M. Forsman. Usability of six observational risk assessment methods. Paper presented at the Proceedings 19th Triennial Congress of the IEA. (2015)

[18] M. E. Chiasson, D. Imbeau, K. Aubry, A. Delisle. Comparing the results of eight methods used to evaluate risk factors associated with musculoskeletal disorders. International Journal of Industrial Ergonomics, 42(5), 478-488. (2012).

[19] G. David, V. Woods, G. Li, P. Buckle. The development of the Quick Exposure Check (QEC) for assessing exposure to risk factors for work-related musculoskeletal disorders. Applied Ergonomics, 39(1), 57-69, (2008).

[20] S. Burt, L. Punnett. Evaluation of interrater reliability for posture observations in a field study. Applied Ergonomics, 30(2), 121-135, (1999). 